\title{
Building better vasculature
}

\author{
Richard K. Bruick and Steven L. McKnight ${ }^{1}$ \\ Department of Biochemistry, University of Texas Southwestern Medical Center, Dallas, Texas 75390, USA
}

Throughout embryogenesis, establishment of the vascular network is mediated by a complex and highly regulated interplay between positive and negative growth factors. In adults, this vascular network is relatively stable and formation of new microvasculature is generally associated with pathophysiological conditions such as tumorigenesis, ischemic insult, and chronic inflammatory diseases. Vascular endothelial growth factor (VEGF) is a critical positive regulator of both physiological and pathophysiological neovascularization. As such, VEGF has become an important therapeutic target in the fight against cancer, blindness resulting from age-related macular degeneration or diabetic retinopathy, and pulmonary hypertension. Conversely, induction of VEGF with the intent to promote angiogenesis may benefit patients suffering from myocardial ischemia, limb ischemia resulting from diabetes, and insufficient wound healing. While overexpression of VEGF alone has been shown to promote angiogenesis, the resulting capillaries are often leaky and accompanied by edema, inflammation, and spontaneous hemorrhagic ulcers. In contrast, the article authored by Elson and colleagues in this issue (Elson et al. 2001) demonstrates that induction of VEGF expression in basal keratinocytes by a constitutively active, gene-specific transcription factor results in increased dermal vascularization devoid of leakage or inflammation. These findings suggest important new therapeutic avenues for promoting angiogenesis and provide a context in which to assess the relative contributions of VEGF to the formation of new vasculature.

\section{VEGF stimulates angiogenesis}

New vasculature networks can arise via de novo assembly (vasculogenesis) or by branching from preexisting vessels (angiogenesis). VEGF is a potent inducer of both processes. VEGF forms active, disulfide-linked homodimers that are recognized by the VEGF receptors (VEGFR-1 and VEGFR-2) expressed in endothelial cells (de Vries et al. 1992; Terman et al. 1992). Five VEGF isoforms, VEGF $121, \mathrm{VEGF}_{145}, \mathrm{VEGF}_{165}, \mathrm{VEGF}_{189}$, and $\mathrm{VEGF}_{201}$, are generated by alternative splicing from a single gene (Houck et al. 1991; Tischer et al. 1991). Although the roles of individual isoforms have not been fully determined, it is clear that VEGF elicits a strong

${ }^{1}$ Corresponding author.

E-MAIL smcKni@biochem.swmed.edu; FAX (214) 648-3346.

Article and publication are at http://www.genesdev.org/cgi/doi/10.1101/ gad.931601. angiogenic response by affecting the survival, proliferation, and migration of vascular tissue (for reviews see Ferrara 1999; Neufeld et al. 1999; Daniel and Abrahamson 2000). For example, VEGF stimulates both the survival and expansion of endothelial cells for assembly into vascular structures (Alon et al. 1995; Gerber et al. 1998 a,b). VEGF promotes the expression of specific proteases required for degradation of endothelial basement membrane (Unemori et al. 1992), initiating the early activation stage of angiogenesis (Daniel and Abrahamson 2000). Initially characterized as an inducer of vascular leakage (Senger et al. 1983), VEGF consequently promotes the leakage of plasma proteins, leading to the formation of an extracellular fibrin gel platform that supports angiogenic branching and tumor cell growth (Dvorak et al. 1987). Following these events, endothelial cells migrate to, and subsequently invade, the vascular stroma. VEGF administration has been shown to promote the recruitment of circulating endothelial progenitor cells into sites of vascular assembly (Asahara et al. 1999) and to activate proteases required for invasion (Pepper et al. 1991).

In fact, VEGF is such a potent angiogenic factor that lone overexpression of individual VEGF isoforms results in the formation of increased vasculature. When overexpressed in keratinocytes by the keratin- 6 promoter, VEGF $_{120}$ stimulates hypervascularization in the skin of transgenic mice (Larcher et al. 1998). However, the resulting tortuous vessels have abnormally large diameters and were found to be leaky and associated with swelling due to severe edema (Larcher et al. 1998). Similarly, keratin-14 promoter-driven overexpression of $\mathrm{VEGF}_{164}$ was shown to increase the density of these same winding, hyperpermeable capillary-like vessels that lead to inflammation of the surrounding skin tissue and the appearance of hemorrhagic ulcers (Detmar et al. 1998; Thurston et al. 1999). Interestingly, when both angiogenic factors $\mathrm{VEGF}_{164}$ and angiopoietin-1 were simultaneously overexpressed by the keratin-14 promoter, the numerous resulting vessels were no longer leaky (Thurston et al. 1999). Together these studies show that VEGF must work in conjunction with other angiogenic factors to produce stable and healthy vasculature.

\section{VEGF expression is induced by hypoxia}

Owing to the critical and varied consequences of VEGF expression, a multitude of signaling pathways regulate VEGF production. In addition to growth factors and cytokines (for reviews, see Ferrara 1999; Neufeld et al. 1999|, VEGF expression is potently up-regulated in re- 
sponse to a low-oxygen, or hypoxic, environment. Initially, VEGF mRNA levels accumulate following exposure to hypoxic conditions. Transcriptional activation of many genes by hypoxia is dependent upon the hypoxiainducible transcription factor, HIF-1 (Semenza 1999). VEGF has been shown to be a bona fide HIF-1 target gene (Carmeliet et al. 1998; Iyer et al. 1998; Ryan et al. 1998), as the VEGF gene contains a hypoxia response element (HRE) within its promoter that is responsive to hypoxiainduced, HIF-1-mediated transcriptional activation (Forsythe et al. 1996). In addition to inducing VEGF gene transcription, hypoxic conditions promote VEGF expression through two additional posttranscriptional mechanisms. First, hypoxia promotes formation of a VEGF mRNA-protein complex within the $3^{\prime}$ untranslated region that enhances the stability of VEGF mRNA /Stein et al. 1995; Levy et al. 1996a,b, 1998; Damert et al. 1997; Claffey et al. 1998). Finally, the 5' untranslated region of the VEGF transcript contains an internal ribosome entry site that may enhance VEGF translation during hypoxic stress (Akiri et al. 1998; Stein et al. 1998).

\section{The gene-specific transcription factor HIF-1 is a central} component of the hypoxia response pathway

The ability to sense and respond to changes in oxygen availability is critical for many developmental, physi- ological, and pathological processes including angiogenesis, control of blood pressure, cerebral and myocardial ischemia, pulmonary hypertension, preeclampsia, and tumorigenesis (Semenza 2000a). In mammalian cells, exposure to a low-oxygen environment triggers an evolutionarily conserved hypoxia response pathway based on the regulated expression of HIF-1 (for review, see Semenza 1999). As shown in Figure 1, HIF-1 is an obligatory heterodimeric protein composed of two members of the basic-helix-loop-helix (bHLH)-containing PER-ARNTSIM (PAS) domain family, HIF- $1 \alpha$ and the aryl hydrocarbon receptor nuclear translocator (ARNT) (Wang et al. 1995). Whereas ARNT expression is not regulated by hypoxia, HIF- $1 \alpha$ is constitutively expressed under normoxic conditions but is rapidly ubiquitinated, targeting the protein for degradation by the proteasome (Salceda and Caro 1997; Huang et al. 1998; Kallio et al. 1999). This regulated instability of HIF- $1 \alpha$ is mediated through its oxygen degradation domain (ODD) (Huang et al. 1998). The ODD contains a conserved proline residue that is hydroxylated under normoxic conditions (Ivan et al. 2001; Jaakkola et al. 2001). When hydroxylated, this proline residue is recognized by the product of the von Hippel-Lindau (pVHL) tumor suppressor gene, a component of a multisubunit ubiquitin-protein ligase (Maxwell et al. 1999; Cockman et al. 2000; Kamura et al. 2000; Ohh et al. 2000; Tanimoto et al. 2000) that polyubiqui-

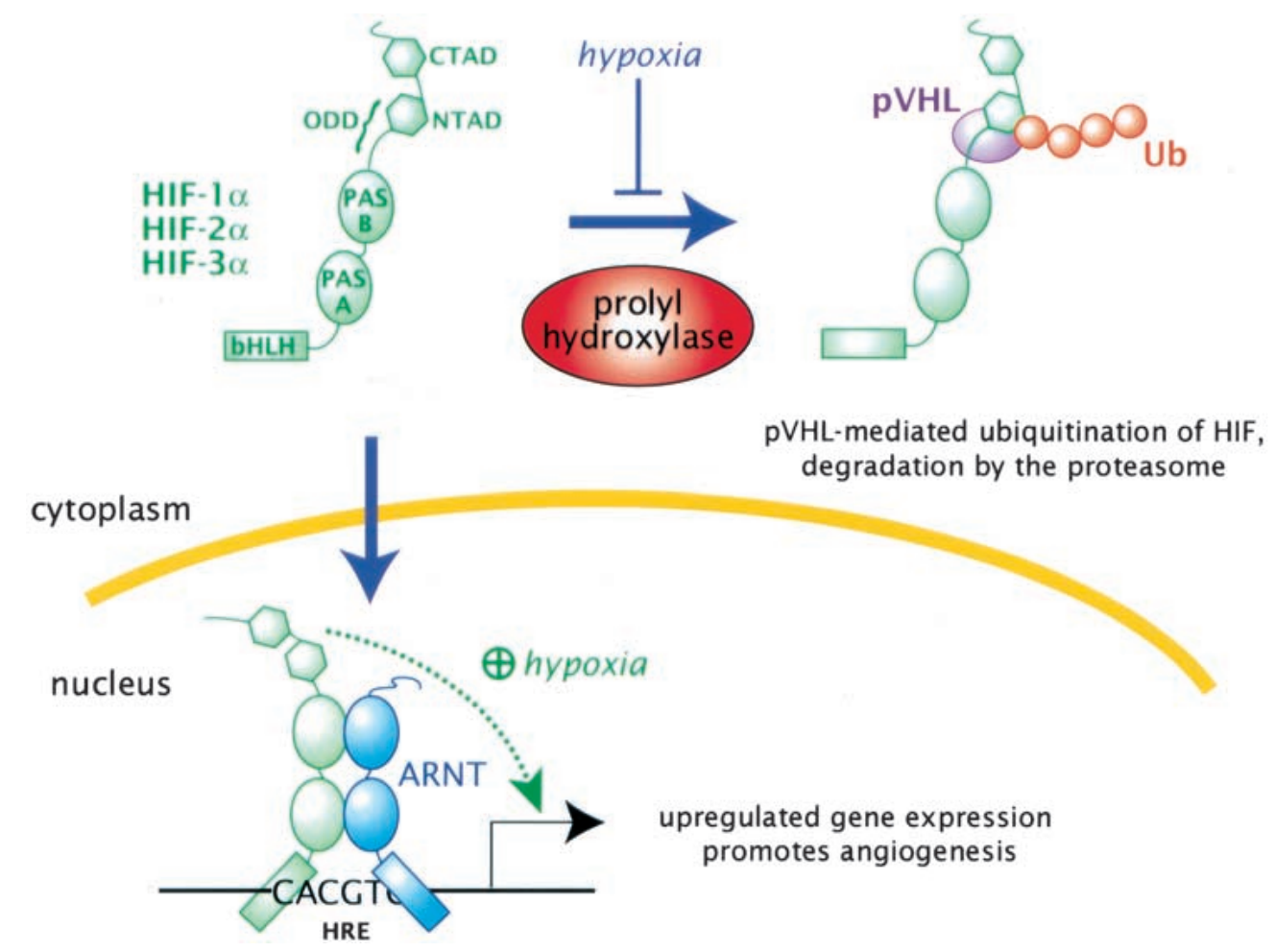

Figure 1. A model for the regulation of the HIF transcription factor. HIF- $1 \alpha$ (or its homologs HIF- $2 \alpha$ and HIF- $3 \alpha$ ) is constitutively expressed. Under normoxic conditions, a proline residue within the oxygen degradation domain (ODD) is hydroxylated by a HIF-prolyl hydroxylase. The modified HIF- $1 \alpha$ polypeptide is recognized by a complex containing pVHL, which targets HIF- $1 \alpha$ for degradation by the proteasome via a polyubiquitin tag. Exposure to a hypoxic environment blocks prolyl hydroxylation, allowing HIF-1 $\alpha$ to accumulate and translocate to the nucleus, where it dimerizes with its partner ARNT. Hypoxia also relieves suppression of the HIF-1 transactivation domains (CTAD and NTAD), promoting transcription of downstream HIF-1 target genes. 
tinates the HIF- $1 \alpha$ polypeptide. Following a shift to a low-oxygen environment, prolyl hydroxylation is blocked and HIF- $1 \alpha$ is stabilized and subsequently translocated into the nucleus (Kallio et al. 1998).

Upon entering the nucleus, HIF- $1 \alpha$ dimerizes with ARNT and binds to HREs within the promoters of its downstream target genes. HIF- $1 \alpha$ contains two transcriptional activation domains bridged by an inhibitory domain (Jiang et al. 1997; Pugh et al. 1997). Exposure to a hypoxic environment relieves suppression of the activation domains, leading to functional association with coactivators such as CBP, p300, SRC-1, and TIF-2 (Kallio et al. 1998; Ema et al. 1999; Carrero et al. 2000) and increased transcription of target genes (for a list of target genes, see Semenza 1999). Two HIF-1 $\alpha$ homologs, designated HIF-2 $\alpha$ /endothelial PAS domain protein (EPAS) (Tian et al. 1997; Wiesener et al. 1998; O'Rourke et al. 1999) and HIF-3 $\alpha$ (Gu et al. 1998; Srinivas et al. 1999), appear to be regulated in a similar manner.

A great deal of work by a number of laboratories has focused on elucidating the molecular mechanism by which cells sense changes in $\mathrm{O}_{2}$ levels and relate those changes to the regulation of the HIF transcription factors. Early evidence suggested that changes in oxygen levels might be detected by a heme-based sensor. The actual nature and identity of the oxygen sensor has remained elusive, however. Several cellular components have been proposed to sense changes in oxygen levels or serve as signaling intermediates which mediate hypoxia response pathway, including the electron transport chain, NADPH oxidoreductases, reactive oxygen species, phosphorylation cascades, $\mathrm{NO}$ and $\mathrm{CO}$, and redoxregulated pathways (for review, see Semenza 1999). Although the relative contribution of these various components to the regulation of HIF-1 stability/activity remains unclear, it is likely that HIF activity is regulated by the integration of many signals. It was recently reported that hydroxylation of a proline residue within the ODD mediates interaction with pVHL under normoxic conditions (Ivan et al. 2001; Jaakkola et al. 2001). Prolyl 4-hydroxylases are known to modify collagen in the endoplasmic reticulum (Kivirikko and Pihlajaniemi 1998); however, these enzymes are unable to modify the ODD (Jaakkola et al. 2001). Like these well characterized enzymes, the HIF prolyl 4-hydroxylase requires $\mathrm{Fe}^{2+}$, ascorbate, 2-oxoglutarate, and $\mathrm{O}_{2}$ (Ivan et al. 2001; Jaakkola et al. 2001), leaving open the possibility that the HIF-prolyl hydroxylase can serve as a direct oxygen sensor.

\section{Overexpression of HIF-1 promotes hypervascularization with fewer defects}

Elson and colleagues surmised that as a potent regulator of VEGF transcription, constitutive expression of HIF-1 might induce angiogenesis. However, moderate overexpression of HIF-1 under normoxic conditions would be expected to have little or no affect on activation of downstream target genes, as the HIF-1 $\alpha$ polypeptide is rapidly degraded. Indeed, placement of the entire HIF-1 $\alpha$ coding region behind the keratin-14 promoter resulted in no ob- servable affect on dermal vascularization despite substantial HIF-1 $\alpha$ mRNA accumulation (Elson et al. 2001). Alternatively, inhibition of the HIF- $1 \alpha$ degradation pathway might be expected to result in HIF- $1 \alpha$ accumulation under normoxic conditions and subsequent transcription of HIF target genes. Transgenic mice engineered to constitutively express from the keratin-14 promoter a HIF$1 \alpha$ polypeptide lacking the 200 amino acids that comprise the ODD (K14-HIF-1 $\alpha \Delta$ ODD) featured increased levels of both VEGF and Glut-1 mRNAs as well as a $66 \%$ increase in dermal capillaries (Elson et al. 2001). Unlike the microvasculature resulting from VEGF overexpression, these perfused dermal capillaries were structurally indistinguishable from normal capillaries in both diameter and morphology. This contrasts sharply with the tortuous vasculature induced by VEGF overexpression alone (Thurston et al. 1999). Because VEGF causes blood vessel permeability, up-regulation of individual VEGF isoforms results in a leaky microvasculature, particularly when exposed to inflammatory stimuli. Despite increased levels of VEGF transcripts detected in the K14HIF- $1 \alpha \Delta$ ODD mice, no increase was observed in vessel leakage or in the number of leakage sites relative to nontransgenic mice, even after treatment with an inflammatory agent (Elson et al. 2001). Consequently, histopathological analysis revealed no associated edema or inflammation with the dermal vasculature (Elson et al. 2001). Unlike the K14-VEGF transgenic mice, K14-HIF$1 \alpha \Delta$ ODD mice did not develop hemorrhagic ulcers or skin tumors as they aged (Elson et al. 2001).

The underlying basis for the differences in vasculature quality arising from overexpression of either VEGF or HIF- $1 \alpha \Delta$ ODD has not been determined. Individual VEGF isoforms likely play distinct roles throughout angiogenesis which cannot be fully recapitulated by a single VEGF isoform. RT-PCR analysis of the K14-HIF$1 \alpha \Delta$ ODD mice demonstrated an increase in the levels of all VEGF splice variants and a relative expression pattern similar to that of nontransgenic mice (Elson et al. 2001). In addition to VEGF, the HIF- $1 \alpha \Delta$ ODD transcription factor activates the expression of other genes including Glut-1 (Elson et al. 2001). Angiopoietin-1 and -2 are also known to be up-regulated in response to hypoxia. When co-overexpressed with VEGF in the skin, these factors promote hypervascularization without the accompanying leakage (Thurston et al. 1999). However, the resulting vasculature is morphologically distinct from normal vessels in both vessel diameter and the number of leakage sites (Thurston et al. 1999). RT-PCR analysis of the K14-HIF- $1 \alpha \Delta$ ODD showed no increase in angiopoieitin-1 and -2 message levels (Elson et al. 2001). Nevertheless, the HIF-1 transcription factor does induce transcription of other factors that influence angiogenesis, including the VEGF receptor Flt-1, nitric oxide synthase-2, endothelin-1, adrenomedullin, heme oxygenase 1, plasminogen activator inhibtor- 1 , and the $\alpha_{1 \mathrm{~B}}$-adrenergic receptor (summarized in Semenza 2000a). One or more of these factors could operate in conjunction with VEGF to produce normal, nonleaky vasculature. Whatever the mechanism, constitutive overexpression of stable HIF-1 
in keratinocytes appears to be more effective in promoting hypervascularization in the skin than VEGF alone. Although HIF-induced angiogenesis in pathophysiological settings such as tumorigenesis or wound repair is often associated with vessel leakage and inflammation, these conditions are also accompanied by differences in the physical and biochemical microenvironment that may impinge upon HIF-induced angiogenesis. Therefore, growth of physiologically normal vasculature may be of therapeutic benefit when locally induced via manipulation of the HIF-dependent hypoxia-response pathway.

\section{Lessons for therapeutic stimulation of angiogenesis}

Because the oxygen supply in primary tumors is limited by diffusion, these cells adapt to the hypoxic environment by promoting the formation of new vasculature. Examination of human gliomas has demonstrated a correlation between HIF-1 expression, tumor vascularization, and tumor grade. Furthermore, loss of HIF-1 can result in tumor latency and decreased vascular density (for review, see Semenza 2000b). Consequently, much attention has been focused on the identification of inhibitors of the hypoxia-response pathway, particularly those that target VEGF expression/activity (for review, see Ferrara and Alitalo 1999; Ferrara 2000). However, patients suffering from a number of pathophysiological disorders resulting from inadequate vascularization may benefit from therapeutic strategies aimed at localized induction of angiogenesis. Preliminary studies have begun to examine the ability of exogenous VEGF to promote angiogenesis in subjects suffering from myocardial or limb ischemia (summarized in Ferrara and Alitalo 1999; Ferrara 2000). Typically, these protocols either administer recombinant VEGF or introduce plasmid DNA encoding VEGF via somatic gene therapy (Baumgartner and Isner 2001). Whereas animal models have shown promise for these therapeutic avenues, early clinical studies have been less encouraging (Ferrara 2000). As the work summarized here suggests, even successful induction of angiogenesis by a single VEGF isoform may still give rise to poor microvasculature accompanied by edema, inflammation, vascular leakage or spontaneous hemorrhagic ulcers. Administration of VEGF in combination with other angiogenic factors such as angiopoietin-1 may alleviate some of the vascular defects (Thurston et al. $1999,2000)$. In addition to the practical drawbacks of administering multiple factors, much work remains in order to resolve the relative contributions and contextdependence of these factors. Of equal concern is that prolonged exposure to high levels of VEGF in the skin (Larcher et al. 1998) or myocardium (Lee et al. 2000) has been shown to accelerate tumor development. VEGF administration was also recently found to be associated with the development of atherosclerosis, possibly by promoting vessel formation or inflammation within atherosclerotic plaques (Celletti et al. 2001). The clinical significance of these observations remains unclear.

The findings presented by Elson et al. (2001) suggest an alternative strategy. Induction of a key upstream transcriptional regulator of VEGF and other proangiogenic factors may result in a more physiological and coordinated induction of angiogenesis. Transfection of naked DNA encoding a chimeric transcription factor composed of the HIF-1 $\alpha$ DNA-binding domain fused to the VP16 transactivation domain in a rabbit hindlimb ischemia model led to enhanced vascular perfusion /Vincent et al. 2000). Although it may also be feasible to attempt to overexpress the constitutively stable HIF- $1 \alpha \Delta$ ODD protein via somatic gene therapy, a much more appealing approach will be to develop small molecule inhibitors of the HIF-1 $\alpha$ degradation pathway. The recent discovery that hydroxylation of a proline residue within the ODD is required for VHL-mediated ubiquitination of HIF-1 $\alpha$ revealed an attractive target for such small molecules.

Of particular interest is the finding that a macrophagederived polypeptide, PR39, induces enhanced formation of functional myocardial vasculature in mice (Li et al. 2000). Under normoxic conditions, PR39 administration resulted in accumulated HIF- $1 \alpha$ protein levels similar to those observed following exposure to hypoxia. HIF-1 $\alpha$ protein accumulation was due to inhibition of ubiquitinproteasome degradation of HIF- $1 \alpha$ and was accompanied by a dose-dependent increase in VEGF mRNA levels (Li et al. 2000). Because PR39 is a proline-rich polypeptide (19 of its 39 residues are proline; Agerberth et al. 1991), it is possible that this peptide blocks the activity of the HIF prolyl hydroxylase. Proline-rich peptides are inhibitors of other prolyl-4-hydroxylases (for review, see Kivirikko and Pihlajaniemi 1998). However, the HIF-1 $\alpha$ protein that accumulates following PR39 treatment is polyubiquitinated (Li et al. 2000), indicating that the block in the degradation pathway may be downstream of the pVHLHIF- $1 \alpha$ interaction. Unlike the accumulated HIF- $1 \alpha$ induced by proteasome inhibitors (Kallio et al. 1999), the ubiquitinated HIF- $1 \alpha$ resulting from PR39 treatment was translocated to the nucleus and was capable of activating transcription of downstream target genes.

Even if PR39 does not affect prolyl hydroxylase activity, inhibitors of known prolyl-4-hydroxylases, including mimics of 2-oxoglutarate, have already been shown to block prolyl hydroxylation of HIF- $1 \alpha$ in vitro and to stabilize the protein under normoxic conditions in vivo (Jaakkola et al. 2001). Identification of the actual HIF-prolyl hydroxylase should allow for the identification of inhibitors demonstrating greater specificity for this enzyme. Although prolonged induction of HIF-1 could also predispose patients to tumor formation, localized and transient application of inhibitors of the HIF-1 degradation pathway might produce results similar to those observed by Elson and colleaguesinduction of a stable and healthy microvasculature.

\section{Acknowledgments}

We thank Kevin Gardner for providing Figure 1. R.K.B. is supported by a National Research Service Award from the National Institutes of Health.

\section{References}

Agerberth, B., Lee, J.-Y., Bergman, T., Carlquist, M., Boman, H.G., Mutt, V., and Jörnvall, H. 1991. Amino acid sequence of PR-39. Eur. J. Biochem. 202: 849-854. 
Akiri, G., Nahari, D., Finkelstein, Y., Le, S.Y., Elroy-Stein, O., and Levi, B.Z. 1998. Regulation of vascular endothelial growth factor (VEGF) expression is mediated by internal initiation of translation and alternative initiation of transcription. Oncogene 17: 227-236.

Alon, T., Hemo, I., Itin, A., Pe'er, J., Stone, J., and Keshet, E. 1995. Vascular endothelial growth factor acts as a survival factor for newly formed retinal vessels and has implications for retinopathy of prematurity. Nat. Med. 1: 1024-1028.

Asahara, T., Takahashi, T., Masuda, H., Kalka, C., Chen, D., Iwaguro, H., Inai, Y., Silver, M., and Isner, J.M. 1999. VEGF contributes to postnatal neovascularization by mobilizing bone marrow-derived endothelial progenitor cells. EMBO J. 18: 3964-3972.

Baumgartner, I. and Isner, J.M. 2001. Somatic gene therapy in the cardiovascular system. Annu. Rev. Physiol. 63: 427-450.

Carmeliet, P., Dor, Y., Herbert, J.M., Fukumura, D., Brusselmans, K., Dewerchin, M., Neeman, M., Bono, F., Abramovitch, R., Maxwell, P., et al. 1998. Role of HIF-1 $\alpha$ in hypoxiamediated apoptosis, cell proliferation and tumour angiogenesis. Nature 394: 485-490.

Carrero, P., Okamato, K., Coumailleau, P., O'Brien, S., Tanaka, H., and Poellinger, L. 2000. Redox-regulated recruitment of the transcriptional coactivators CREB-binding protein and SRC-1 to hypoxia-inducible factor 1a. Mol. Cell. Biol. 20: 402-415.

Celletti, F.L., Waugh, J.M., Amabile, P.G., Brendolan, A., Hilfiker, P.R., and Dake, M.D. 2001. Vascular endothelial growth factor enhances atherosclerotic plaque progression. Nat. Med. 7: 425-429.

Claffey, K.P., Shih, S.C., Mullen, A., Dziennis, S., Cusick, J.L., Abrams, K.R., Lee, S.W., and Detmar, M. 1998. Identification of a human VPF/VEGF 3' untranslated region mediating hypoxia-induced mRNA stability. Mol. Biol. Cell 9: 469-481.

Cockman, M.E., Masson, N., Mole, D.R., Jaakkola, P., Chang, G.W., Clifford, S.C., Maher, E.R., Pugh, C.W., Ratcliffe, P.J., and Maxwell, P.H. 2000. Hypoxia inducible factor-a binding and ubiquitylation by the von Hippel-Lindau tumor suppressor protein. J. Biol. Chem. 275: 25733-25741.

Damert, A., Machein, M., Breier, G., Fujita, M.Q., Hanahan, D., Risau, W., and Plate, K.H. 1997. Up-regulation of vascular endothelial growth factor expression in a rat glioma is conferred by two distinct hypoxia-driven mechanisms. Cancer Res. 57: 3860-3864.

Daniel, T.O. and Abrahamson, D. 2000. Endothelial signal integration in vascular assembly. Annu. Rev. Physiol. 62: 649-671.

de Vries, C., Escobedo, J.A., Ueno, H., Houck, K., Ferrara, N., and Williams, L.T. 1992. The fms-like tyrosine kinase, a receptor for vascular endothelial growth factor. Science 255: 989-991.

Detmar, M., Brown, L.F., Schon, M.P., Elicker, B.M., Velasco, P., Richard, L., Fukumura, D., Monsky, W., Claffey, K.P., and Jain, R.K. 1998. Increased microvascular density and enhanced leukocyte rolling and adhesion in the skin of VEGF transgenic mice. J. Invest. Dermatol. 111: 1-6.

Dvorak, H.F., Harvey, V.S., Estrella, P., Brown, L.F., McDonagh, J., and Dvorak, A.M. 1987. Fibrin containing gels induce angiogenesis. Implications for tumor stroma generation and wound healing. Lab. Invest. 57: 673-686.

Elson, D.A., Thurston, G., Huang, L.E., Ginzinger, D.G., McDonald, D.M., Johnson, R.S., and Arbeit, J.M. 2001. Induction of hypervascularity without leak or inflammation in transgenic mice overexpressing hypoxia-inducible factor-1a. Genes \& Dev. 15: 2520-2532 (this issue).

Ema, M., Hirota, K., Mimura, J., Abe, H., Yodoi, J., Sogawa, K., Poellinger, L., and Fujii-Kuriyama, Y. 1999. Molecular mechanisms of transcription activation by HLF and HIF $1 \alpha$ in response to hypoxia: Their stabilization and redox signalinduced interaction with CBP/p300. EMBO J. 18: 1905-1914.

Ferrara, N. 1999. Molecular and biological properties of vascular endothelial growth factor. J. Mol. Med. 77: 527-543.

- 2000. VEGF: An update on biological and therapeutic aspects. Curr. Opin. Biotechnol. 11: 617-624.

Ferrara, N. and Alitalo, K. 1999. Clinical applications of angiogenic growth factors and their inhibitors. Nat. Med. 5: 13591364.

Forsythe, J.A., Jiang, B.H., Iyer, N.V., Agani, F., Leung, S.W., Koos, R.D., and Semenza, G.L. 1996. Activation of vascular endothelial growth factor gene transcription by hypoxia-inducible factor 1. Mol. Cell. Biol. 16: 4604-4613.

Gerber, H.P., Dixit, V., and Ferrara, N. 1998a. Vascular endothelial growth factor induces expression of the antiapoptotic proteins Bcl-2 and A1 in vascular endothelial cells. J. Biol. Chem. 273: 13313-13316.

Gerber, H.P., McMurtrey, A., Kowalski, J., Yan, M., Keyt, B.A., Dixit, V., and Ferrara, N. 1998b. Vascular endothelial growth factor regulates endothelial cell survival through the phosphatidylinositol 3'-kinase/Akt signal transduction pathway. Requirement for Flk-1/KDR activation. J. Biol. Chem. 273: 30336-30343.

Gu, Y.Z., Moran, S.M., Hogenesch, J.B., Wartman, L., and Bradfield, C.A. 1998. Molecular characterization and chromosomal localization of a third alpha-class hypoxia inducible factor subunit, HIF3alpha. Gene Expr. 7: 205-213.

Houck, K.A., Ferrara, N., Winer, J., Cachianes, G., Li, B., and Leung, D.W. 1991. The vascular endothelial growth factor family: Identification of a fourth molecular species and characterization of alternative splicing of RNA. Mol. Endocrinol. 5: $1806-1814$

Huang, L.E., Gu, J., Schau, M., and Bunn, H.F. 1998. Regulation of hypoxia-inducible factor lalpha is mediated by an $\mathrm{O} 2$ dependent degradation domain via the ubiquitin-proteasome pathway. Proc. Nat1. Acad. Sci. 95: 7987-7992.

Ivan, M., Kondo, K., Yang, H., Kim, W., Valiando, J., Ohh, M., Salic, A., Asara, J.M., A.J., Lane, W.S., and Kaelin, Jr., W.G. 2001. HIFa targeted for VHL-mediated destruction by proline hydroxylation: Implications for $\mathrm{O}_{2}$ sensing. Science 292: 464-468.

Iyer, N.V., Kotch, L.E., Agani, F., Leung, S.W., Laughner, E., Wenger, R.H., Gassmann, M., Gearhart, J.D., Lawler, A.M., Yu, A.Y., et al. 1998. Cellular and developmental control of $\mathrm{O}_{2}$ homeostasis by hypoxia-inducible factor 1 alpha. Genes \& Dev. 12: 149-162.

Jaakkola, P., Mole, D.R., Tian, Y.-M., Wilson, M.I., Gielbert, J., Gaskell, S.J., von Kriegsheim, A., Hebestreit, H.F., Mukherii, M., Schofield, C.J., et al. 2001. Targeting of HIF-a to the von Hippel-Lindau ubiquitylation complex by $\mathrm{O}_{2}$-regulated prolyl hydroxylation. Science 292: 468-472.

Jiang, B.H., Zheng, J.Z., Leung, S.W., Roe, R., and Semenza, G.L. 1997. Transactivation and inhibitory domains of hypoxiainducible factor 1alpha. Modulation of transcriptional activity by oxygen tension. J. Biol. Chem. 272: 19253-19260.

Kallio, P.J., Okamoto, K., O’Brien, S., Carrero, P., Makino, Y., Tanaka, H., and Poellinger, L. 1998. Signal transduction in hypoxic cells: Inducible nuclear translocation and recruitment of the $\mathrm{CBP} / \mathrm{p} 300$ coactivator by the hypoxia-inducible factor-1alpha. $E M B O$ J. 17: 6573-6586.

Kallio, P.J., Wilson, W.J., O'Brien, S., Makino, Y., and Poellinger, L. 1999. Regulation of the hypoxia-inducible transcription factor 1alpha by the ubiquitin-proteasome pathway. J. Biol. Chem. 274: 6519-6125.

Kamura, T., Sato, S., Iwai, K., Czyzyk-Krzeska, M., Conaway, R.C., and Conaway, J.W. 2000. Activation of HIF1 $\alpha$ ubiqui- 
tination by a reconstituted von Hippel-Lindau (VHL) tumor suppressor complex. Proc. Natl. Acad. Sci. 97: 10430-10435.

Kivirikko, K.I. and Pihlajaniemi, T. 1998. Collagen hydroxylases and the protein disulfide isomerase subunit of prolyl 4-hydroxylases. In Advances in enzymology and related areas of molecular biology (ed. D.L. Purich), pp. 325-398. J. Wiley, New York, NY.

Larcher, F., Murillas, R., Bolontrade, M., Conti, C.J., and Jorcano, J.L. 1998. VEGF/VPF overexpression in skin of transgenic mice induces angiogenesis, vascular hyperpermeability and accelerated tumor development. Oncogene 17: 303 311 .

Lee, R.J., Springer, M.L., Blanco-Bose, W.E., Shaw, R., Ursell, P.C., and Blau, H.M. 2000. VEGF gene delivery to myocardium: Deleterious effects of unregulated expression. Circulation 102: 898-901.

Levy, A.P., Levy, N.S., and Goldberg, M.A. 1996a. Hypoxia-inducible protein binding to vascular endothelial growth factor mRNA and its modulation by the von Hippel-Lindau protein. J. Biol. Chem. 271: 25492-25497.

. 1996b. Post-transcriptional regulation of vascular endothelial growth factor by hypoxia. J. Biol. Chem. 271: 27462753.

Levy, N.S., Chung, S., Furneaux, H., and Levy, A.P. 1998. Hypoxic stabilization of vascular endothelial growth factor mRNA by the RNA-binding protein HuR. J. Biol. Chem. 273: 6417-6423.

Li, J., Post, M., Volk, R., Gao, Y., Li, M., Metais, C., Sato, K., Tsai, J., Aird, W., Rosenberg, R.D., et al. 2000. PR39, a peptide regulator of angiogenesis. Nat. Med. 6: 49-55.

Maxwell, P.H., Wiesener, M.S., Chang, G.W., Clifford, S.C., Vaux, E.C., Cockman, M.E., Wykoff, C.C., Pugh, C.W., Maher, E.R., and Ratcliffe, P.J. 1999. The tumour suppressor protein VHL targets hypoxia-inducible factors for oxygendependent proteolysis. Nature 399: 271-275.

Neufeld, G., Cohen, T., Gengrinovitch, S., and Poltorak, Z. 1999. Vascular endothelial growth factor (VEGF) and its receptors. FASEB T. 13: 9-22.

O'Rourke, J.F., Tian, Y.M., Ratcliffe, P.J., and Pugh, C.W. 1999. Oxygen-regulated and transactivating domains in endothelial PAS protein 1: Comparison with hypoxia-inducible factor1alpha. J. Biol. Chem. 274: 2060-2071.

Ohh, M., Park, C.W., Ivan, M., Hoffman, M.A., Kim, T.-Y., Huang, L.E., Pavletich, N., Chau, V., and Kaelin, Jr., W.G. 2000. Ubiquitination of hypoxia-inducible factor requires direct binding to the $\beta$-domain of the von Hippel-Lindau protein. Nat. Cell Biol. 2: 423-427.

Pepper, M.S., Ferrara, N., Orci, L., and Montesano, R. 1991. Vascular endothelial growth factor (VEGF) induces plasminogen activators and plasminogen activator inhibitor-1 in microvascular endothelial cells. Biochem. Biophys. Res. Comm. 181: 902-906.

Pugh, C.W., O'Rourke, J.F., Nagao, M., Gleadle, J.M., and Ratcliffe, P.J. 1997. Activation of hypoxia-inducible factor-1, definition of regulatory domains within the alpha subunit. J. Biol. Chem. 272: 11205-11214.

Ryan, H.E., Lo, J., and Johnson, R.S. 1998. HIF-1 $\alpha$ is required for solid tumor formation and embryonic vascularization. EMBO I. 17: 3005-3015.

Salceda, S. and Caro, J. 1997. Hypoxia-inducible factor lalpha $(\mathrm{HIF}-1 \alpha)$ protein is rapidly degraded by the ubiquitin-proteasome system under normoxic conditions. Its stabilization by hypoxia depends on redox-induced changes. J. Biol. Chem. 272: 22642-22647.

Semenza, G.L. 1999. Regulation of mammalian $\mathrm{O}_{2}$ homeostasis by hypoxia-inducible factor 1. Annu. Rev. Cell Dev. Biol. 15: $551-578$.

. 2000a. HIF-1 and human disease: One highly involved factor. Genes \& Dev. 14: 1983-1991.

. 2000b. Hypoxia, clonal selection, and the role of HIF-1 in tumor progression. Crit. Rev. Biochem. Mol. Biol. 35: 71-103.

Senger, D.R., Galli, S.J., Dvorak, A.M., Perruzzi, C.A., Harvey, V.S., and Dvorak, H.F. 1983. Tumor cells secrete a vascular permeability factor that promotes accumulation of ascites fluid. Science 219: 983-985.

Srinivas, V., Zhang, L.P., Zhu, X.H., and Caro, J. 1999. Characterization of an oxygen/redox-dependent degradation domain of hypoxia-inducible factor alpha (HIF- $\alpha$ ) proteins. Biochem. Biophys. Res. Comm. 260: 557-561.

Stein, I., Neeman, M., Shweiki, D., Itin, A., and Keshet, E. 1995. Stabilization of vascular endothelial growth factor mRNA by hypoxia and hypoglycemia and coregulation with other ischemia-induced genes. Mol. Cell. Biol. 15: 5363-5368.

Stein, I., Itin, A., Einat, P., Skaliter, R., Grossman, Z., and Keshet, E. 1998. Translation of vascular endothelial growth factor mRNA by internal ribosome entry: Implications for translation under hypoxia. Mol. Cell. Biol. 18: 3112-3119.

Tanimoto, K., Makino, Y., Pereira, T., and Poellinger, L. 2000. Mechanism of regulation of the hypoxia-inducible factor- $1 \alpha$ by the von Hippel-Lindau tumor suppressor protein. EMBO J. 19: 4298-4309.

Terman, B.I., Dougher-Vermazen, M., Carrion, M.E., Dimitrov, D., Armellino, D.C., Gospodarowicz, D., and Bohlen, P. 1992. Identification of the KDR tyrosine kinase as a receptor for vascular endothelial cell growth factor. Biochem. Biophys. Res. Comm. 187: 1579-1586.

Thurston, G., Suri, C., Smith, K., McClain, J., Sato, T.N., Yancopoulos, G.D., and McDonald, D.M. 1999. Leakage-resistant blood vessels in mice transgenically overexpressing angiopoietin-1. Science 286: 2511-2514.

Thurston, G., Rudge, J.S., Ioffe, E., Zhou, H., Ross, L., Croll, S.D., Glazer, N., Holash, J., McDonald, D.M., and Yancopoulos, G.D. 2000. Angiopoietin-1 protects the adult vasculature against plasma leakage. Nat. Med. 6: 460-463.

Tian, H., McKnight, S.L., and Russell, D.W. 1997. Endothelial PAS domain protein 1 (EPAS1), a transcription factor selectively expressed in endothelial cells. Genes \& Dev. 11: 72-82.

Tischer, E., Mitchell, R., Hartman, T., Silva, M., Gospodarowicz, D., Fiddes, J.C., and Abraham, J.A. 1991. The human gene for vascular endothelial growth factor. Multiple protein forms are encoded through alternative exon splicing. J. Biol. Chem. 266: 11947-11954.

Unemori, E.N., Ferrara, N., Bauer, E.A., and Amento, E.P. 1992. Vascular endothelial growth factor induces interstitial collagenase expression in human endothelial cells. J. Cell. Physiol. 153: 557-562.

Vincent, K.A., Shyu, K.G., Luo, Y., Magner, M., Tio, R.A., Jiang, C., Goldberg, M.A., Akita, G.Y., Gregory, R.J., and Isner, J.M. 2000. Angiogenesis is induced in a rabbit model of hindlimb ischemia by naked DNA encoding an HIF- $1 \alpha / \mathrm{VP} 16$ hybrid transcription factor. Circulation 102: 2255-2261.

Wang, G.L., Jiang, B.H., Rue, E.A., and Semenza, G.L. 1995 Hypoxia-inducible factor 1 is a basic-helix-loop-helix-PAS heterodimer regulated by cellular $\mathrm{O} 2$ tension. Proc. Nat1. Acad. Sci. 92: 5510-5514.

Wiesener, M.S., Turley, H., Allen, W.E., Willam, C., Eckardt, K.U., Talks, K.L., Wood, S.M., Gatter, K.C., Harris, A.L., Pugh, C.W., et al. 1998. Induction of endothelial PAS domain protein-1 by hypoxia: Characterization and comparison with hypoxia-inducible factor-1alpha. Blood 92: 2260-2268. 


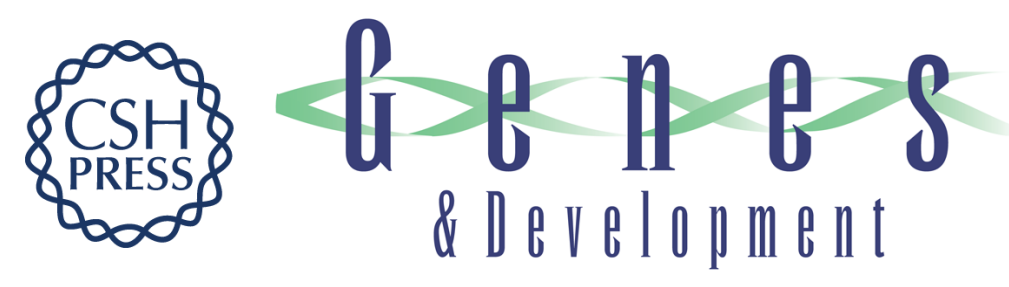

\section{Building better vasculature}

Richard K. Bruick and Steven L. McKnight

Genes Dev. 2001, 15:

Access the most recent version at doi:10.1101/gad.931601

References This article cites 64 articles, 38 of which can be accessed free at: http://genesdev.cshlp.org/content/15/19/2497.full.html\#ref-list-1

License

Email Alerting Receive free email alerts when new articles cite this article - sign up in the box at the top Service right corner of the article or click here.

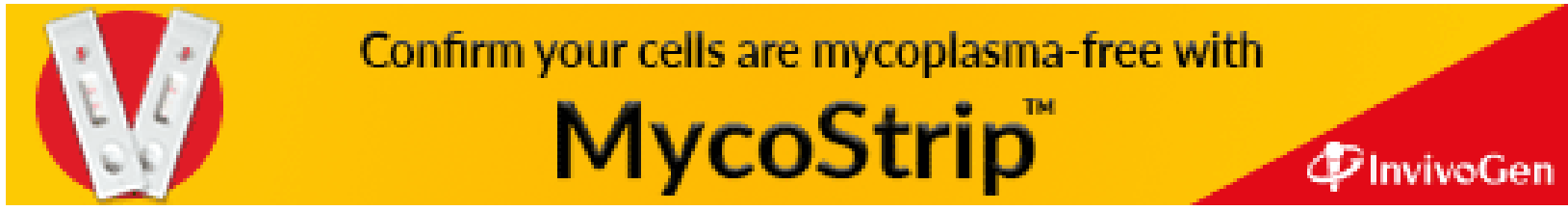

